УДК 785.11(510:4)"18"(045)

ORCID ID: https://orcid.org/0000-0002-3270-4622

Ян Цзюнь,

аспірант кафедри теорії та історії культури. Національна музична академія України імені П. І. Чайковського, Київ

Yang Jun,

Postgaduate Student of the Theory and History of Culture Department.

Ukrainian National Tchaikovsky Academy of Music, Kyiv

\title{
СТАНОВЛЕННЯ Й РОЗВИТОК СИМФОНІЧНОЇ МУЗИКИ КИТАЮ В АСПЕКТІ ПРОБЛЕМИ ДІАЛОГУ КУЛЬТУР
}

\begin{abstract}
Анотація. Статтю присвячено висвітленню процесів становлення і розвитку симфонічної музики Китаю, що розгорталися з кінця ХІХ ст. в результаті засвоєння моделей західної музичної культури. Простежено дію механізмів культурної дифузії, синтезу та асиміляції, шлях до стильової адаптації та стильової генерації симфонічної музики в Китаї у різних проявах: інституційному, освітньому, виконавському, композиторському. Продемонстровано універсалізм творчих особистостей діячів мистецтва Китаю.

Ключові слова: діалог культур, симфонічна музика Китаю, композиторська творчість, симфонічні оркестри, музична освіта.
\end{abstract}

Постановка проблеми та актуальність дослідження. Соціокультурний простір сучасного Китаю представлений надзвичайно різноманітними мистецькими видами та формами: від традиційних, що укорінені в багатовіковій національній культурі, до авангардних, що стали результатом сучасних міжкультурних комунікацій. Своєю нинішньою множинністю він завдячує специфіці історичного розвитку вітчизняного мистецтва та країни загалом. Дослідження особливостей соціокультурного простору Китаю $є$ важливим як $з$ позицій сучасних мистецьких процесів, так і в ракурсі осмислення міжкультурної взаємодії.

У музичній культурі сучасного Китаю особливе місце посідає симфонічна музика. Запозичена 3 культури Заходу на початку XX ст. у процесах культурної дифузії, ця жанрова сфера укорінилась у соціокультурному просторі країни, пройшовши етапи синтезу та асиміляції.

Mema cmammi - на конкретних прикладах висвітлити головні чинники процесів становлення й розвитку китайського симфонізму в його інституційних, композиторських, виконавських та освітніх проявах.

Аналіз останніх досліджень і публікацій. Різні сторони взаємодії культур по осі Схід-Захід досліджувалися в цілій низці музикознавчих і культурологічних праць останніх десятиліть, зокрема в працях молодих китайських дослідників в Україні. Проблема висвітлювалася в різних аспектах: від загальних засад міжкультурних комунікацій до їх проявів у конкретних жанрово-стильових сферах. Назвемо деякі $з$ досліджень такого роду.

Проблеми проявів конвергенції східної та західної художньої традиції у композиторській практиці розглядав Чжу Чанлей, який провів паралелі між симфонічною творчістю Бао Юань Кея (Китай) та Євгена Станковича (Україна), знаходячи між їхніми індивідуальними авторськими системами певні риси подібності (Чжу Чанлей, 2006). Приділялася також пильна увага компаративному аналізу творчих здобутків представників китайської й західних композиторських шкіл у різних жанрах: духової (Ден Цзякунь, 2019), фортепіанної (Лі Цзінь, 2012), камерно-інструментальної музики (Ху Пін, 2013).

Увагу дослідників привертали також різноманітні прояви діалогу культур у сфері театру, зокрема музичного. «Висвітленню змістових та жанровостильових взаємовідображень оперного мистецтва великих цивілізацій Китаю та Європи, їх взаємовпливів та взаємосприйняття» (Лі Мін, 2019 , с. 16) присвятив своє дисертаційне дослідження Лі Мін. Подібна проблематика, а саме паралелі художнього розвитку європейського та китайського оперного театру, опинилася в центрі 
уваги Ту Дуня (Ту Дуня, 2010). Міжкультурну взаємодію в сфері театрального мистецтва, що триває більше ста років, досліджував Янь Чао, який висвітлив трансформацію модусу європейського драматичного театру на китайському грунті (Янь Чао, 2019).

При цьому проблема становлення й розвитку симфонічної музики в аспекті механізмів реалізації діалогу культур залишається не вповні висвітленою.

Виклад основного матеріалу. Нині загальновизнано, що традиції культур Заходу і Сходу суттєво розрізняються між собою, оскільки мають у своїй основі принципово різні архетипи. Як справедливо зазначено в розгорнутій енциклопедичній статті «Китайсько-українські музичні зв' язки», порівняно з Європою «азійський Китай має кардинальні відмінності щодо мови (інтонаційної у всіх різноманітних діалектах), писемності (ієрогліфічної), релігії та філософії (даосизм, конфуціанство), історико-культурного і практично-побутового досвіду, національної ментальності і традицій світосприймання» (Берегова, Муха, Шип, 2008, с. 403). Разом із тим, інтеграційні процеси в культурі XX ст. спричинилися до взаємного збагачення соціокультурного середовища різних країн, засвоєння мистецького досвіду, що виник на подеколи зовсім далекому культурному грунті.

Подібні процеси постають як прояви діалогу культур - складного й багаторівневого явища. «Культура $є$ формою одночасного буття й спілкування людей різних - минулих, теперішніх та майбутніх - культур», - стверджував В. Біблер. Більше того, діалог, на думку вченого, $є$ атрибутом культури: «Культура стає культурою лише в цій одночасності спілкування різних культур» (Біблер, Ахутин, 2000-2001).

Механізми засвоєння культурних моделей, що сформувалися в тій чи іншій країні та поширили ареал свого функціонування на інші терени, простежуються істориками художньої культури на прикладі різних жанрів. Одним з найпоказовіших стала опера, що зобов'язана своїм походженням Італії. Впродовж більш як чотирьох століть існування опера стала явищем світового значення, утворивши численні національні варіанти та жанрові модифікації. Спочатку відбувається дифузія - процес «просторового поширення культурних здобутків одного суспільства в іншому» (Семенов, 1997 , с. 105). Олена Зінькевич визначає дифузію як «проникнення, вільне розміщення елементів однієі традиції між елементами іншої» і стверджує, що наступними етапами стають синтез («отримання нової цілісності з елементів, що входять в "реакцію взаємодії”») та асиміляція («національне засвоєння сприйнятого») (Зінькевич, 1986, с. 15). Результатом стає формування явищ, яким притаманна нова художня якість, оскільки вони виникають в результаті синтезу різнорідних елементів. Подібні механізми переконливо висвітлені у дослідженні зародження й формування російської опери, здійсненому Сергієм Тишко. Вчений пише про два етапи формування нового явища на основі запозиченої моделі: стильової адаптації- «пошуку точок дотику між «своїм» і «чужим» матеріалом, рух до їх стильового компромісу» (Тишко, 1994, c. 7), а згодом стильової генерації - «створення нових стильових ознак на основі власного національного матеріалу, в умовах його певної опозиції до позанаціонального» (Тишко, 1994, с. 11).

Дію цих універсальних механізмів можна простежити і в процесах становлення й розвитку китайської симфонічної музики. Початкове проникнення до Китаю у перші десятиліття XX ст. симфонічних жанрів як вияву чужорідних для країни мистецьких форм пов'язане зі специфікою соціокультурного простору деяких великих міст, зокрема Шанхая та Харбіна.

На території Шанхая впродовж більш як ста років, з середини XIX до середини XX ст., існували так звані сетлменти - ділянки-квартали, що здавалися в оренду іноземним державам і мали статус екстериторіальності: французький (1849-1946) та британський, пізніше перейменований на Шанхайський міжнародний сетлмент (1842-1943). Їхню діяльність регулювала утворена в 1854 р. об'єднана Муніципальна рада. Саме тут у 1879 р. був заснований перший в Китаї (і в Азії загалом) оркестр європейського типу - Шанхайський публічний оркестр, створений за зразком воєнного духового оркестру. Згодом, на початку XX ст., оркестр включив струнну групу, поступово збільшивши загальну кількість музикантів до тридцяти дев'яти, що дало підстави називатися симфонічним оркестром. 31922 р. колектив отримав назву «Симфонічний оркестр Шанхайської муніципальної ради».

Історія Шанхайського симфонічного оркестру, що існує і донині, $є$ віддзеркаленням процесів становлення симфонічної музики в Китаї загалом. Першими диригентами оркестру були європейські музиканти: флейтист з Франції Жан Ремюз, диригент з Німеччини Рудольф Бак, піаніст-віртуоз 3 Італії Маріо Пачі. Кожен з них зробив значний внесок у становлення оркестру, однак кристалізація його відбулася в «еру Пачі». 23 листопада 1919 р. під орудою М. Пачі відбувся перший в Азії сим- 
фонічний концерт, до програми якого було включено П'яту симфонію Л. Бетховена і сюїту «Пер Гюнг» Е. Гріга. Завдяки зусиллям М. Пачі якісно змінилося коло слухачів - було отримано дозвіл відвідувати концерти китайцям, а не лише іноземцям, які мешкали в Китаї, як це було від початку. Завдяки позиції диригента місцеві музиканти поступово одержали право грати в оркестрі. Як результат, у китайській прем'єрі Дев'ятої симфонії Л. Бетховена, що відбулася в 1936 р., взяли участь досить багато китайців-оркестрантів. Показово, що сам Маріо Пачі мав китайське ім'я - Мей Байци, що свідчить про його інтеграцію до середовища країни, якій він присвятив значну частину свого життя.

Видається очевидним, що діяльність оркестру на цьому початковому етапі стала чинником дифузії, впровадження елементів музичної культури Заходу в її симфонічному вимірі на китайський грунт. Несприятливі соціокультурні обставини наступного періоду (від 1936 р.) спричинилися до призупинення, а згодом трансформації роботи колективу. У другій половині 1940-х рр. європейські музиканти залишали Китай, i на їх місце прийшли китайські виконавці. 3 цього часу керівниками оркестру виступали винятково китайські диригенти. Еволюція оркестру доводить факт засвоєння західної моделі на виконавському рівні.

Подібні процеси відбувалися на початку XX ст. в місті Харбін, що знаходиться в іншому регіоні Китаю. Значну частину населення міста, заснованого в 1898 р. із розбудовою Китайсько-Східної залізниці, становили іммігранти з Російської імпеpiï. Утворений тут у 1908 р. симфонічний оркестр спочатку мав у своєму складі переважно аматорів, але з часом дедалі інтенсивніше професіоналізувався. Особливої динамічності цей процес набув після 1917 р., коли хвиля імміграції природним чином посилилася. Рівень оркестру був настільки високим, що в 1920-х рр. диригента Е. Меттера і тридцятьох оркестрантів було запрошено до Японії для заснування оркестру при імператорському дворі (Дівєєва, 2014, с. 68). При цьому оркестр достатньо швидко компенсував цю втрату, залучивши нових музикантів. До репертуару входили симфонічні твори європейських композиторів, зокрема російська музична класика. Навколо оркестру 3 часом нарощувалася відповідна інституційна складова: у 1935 р. було організовано Харбінське симфонічне товариство, до складу якого увійшли переважно музиканти оркестру, передбачалося створення Клубу любителів симфонічної музики, з 1940 р. товариство видавало щомісячний журнал для висвітлення діяльності оркестру та актуальних проблем європейського концертного життя. Після 1946 р. в Харбіні стали формуватися оркестри, що складалися 3 китайських музикантів.

Успішне функціонування оркестрів і поступове залучення до їх складу китайських виконавців загострило проблему підготовки професійних кадрів. Було здійснено організаційні зусилля зі створення закладів, що здійснювали навчання молодих музикантів.

У Харбіні музична школа була відкрита в 1928 p. (з 1929 р. вона отримала назву «Національна музична школа»), що дало можливість надати музичну освіту багатьом поколінням митців. 3 моменту іiі заснування в школі навчалося близько 100 відомих музикантів», - стверджує Лю Яньтао, заступник керівника Харбінського бюро культури, преси та публікацій (Wang Hanlu, 2010).

Зазначимо, що багаторічна діяльність у сфері академічної музики в Харбіні, що тривала впродовж багатьох десятиліть, у XXI ст. отримала визнання на міжнародному рівні. У червні 2010 p. Харбіну було присуджено відзнаку ООН «Музичне місто» за музичні досягнення міста та його мешканців, яку вручили представникам міської громади в Барселоні (Wang Hanlu, 2010).

Автором програми, за якою здійснювалося навчання в Національній музичній школі від самого її заснування, був Сяо Юмей (1884-1940). При створенні програми він спирався на систему навчання в Лейпцігській консерваторії, яку закінчив сам, захистивши дисертацію доктора філософiї (1916). Запровадження такої програми сприяло адаптації моделей західної музичної культури ще й на освітньому рівні.

Взаємодія культур, що реалізовувалася в китайській симфонічній музиці впродовж кількох десятиліть поспіль, наочно простежується в діяльності кількох поколінь музикантів - композиторів, теоретиків, диригентів, виконавців. При цьому дуже важливими були і мотивація музичних діячів, і особисті зусилля, яких вони докладали в своєму прагненні до досконалості. Об'єктивний стан китайської симфонічної музики спонукав китайських музикантів до багатогранної активності, до поєднання різних сфер діяльності. Приміром, згаданий вище Сяо Юмей прославився не лише як музичний педагог, а й як теоретик і композитор. Наукова методологія, 3 якою він ознайомився під час навчання у видатного німецького вченого Гуго Римана в Лейпцигу, застосовувалася ним для дослідження питань історії китайської музики. Захищена ним дисертація доктора філософії була присвячена ви- 
світленню особливостей китайської оркестрової музики до XVII ст. Осягнення національної традиції дало дослідникові можливість сформувати власний оригінальний погляд на традиції західної музики, в тому числі симфонічної. Це своєю чергою вплинуло на композиторську творчість Сяо Юмея: він був одним 3 перших китайських композиторів, хто застосував у своїй творчості запозичені з західної музичної культури композиційні прийоми.

Отримана за межами Китаю музична освіта вже в першій половині XX ст. допомагала китайським композиторам здійснювати спроби створювати власний національний стиль, синтезуючи елементи різних культур, сприяючи адаптації в Китаї моделей західної симфонічної музики. Показова в цьому сенсі постать Хуан Цзи (1904-1938), який пройшов навчальний курс в університеті Цинхуа (Пекін), а згодом продовжив отримувати освіту в США, зосередившись на вивченні історії й теорії музики. Саме Хуан Цзи став автором першого великого симфонічного твору в історії китайської музики - увертюри «Ностальгічна фантазія» («In Memoriam»), написаної ним у 1928 р. під час перебування в Сльському університеті та присвяченої пам'яті померлої нареченої молодого митця, піаністки Ху Юнфу. По поверненні до Китаю Хуан Цзи активно включився до різних видів музичної діяльності, прагнучи сприяти засвоєнню китайськими музикантами нових для країни жанрових сфер і у власній творчості, і у педагогічній роботі (він викладав у Національній музичній школі в Шанхаї).

Нової якості набули зусилля китайських музикантів після Другої світової війни. До наступного покоління митців, що сприяли розвиткові китайського симфонізму, належить Лі Делунь (19172001) - видатний диригент, чиє життя було віддане служінню мистецтву. Він став одним з фундаторів виконавської традиції класичного симфонізму в Китаї. Про авторитет музиканта в країні свідчить та обставина, що $з$ його іменем тут асоціюється сама диригентська майстерність і від 2012 р. проводиться Національний конкурс диригентів імені Лі Делуня (Smith, 2012).

Показово, що свою музичну освіту митець, так само як і його згадані нами попередники, завершував поза межами Китаю. Вже дорослим, сформованим музикантом Лі Делунь вступив до Московської консерваторії, де навчався у класі Миколи Аносова. Діяльність М. Аносова, попри специфіку соціокультурної ситуації СРСР 1950-х pp., у професійних проявах була глибоко інтегро- вана до європейської музичної традиції. Вільне володіння кількома іноземними мовами дало змогу М. Аносову ознайомитися 3 працями провідних діячів музичного мистецтва, а також перекласти й підготувати до видання в СРСР фундаментальні праці, присвячені основоположним професійним проблемам: «Про диригування» славетного англійського музиканта Генрі Вуда (видано в перекладі М. Аносова в 1958 р.), а також «Я - диригент» французького митця Шарля Мюнша (видано в 1960 р.). Оскільки Лі Делунь навчався у класі М. Аносова в період роботи останнього над перекладами названих праць, можна обгрунтовано припустити, що китайський музикант отримав вичерпну інформацію не лише про методи роботи з оркестром свого викладача, а й (опосередковано) про здобутки його західних колег.

Подальша діяльність Лі Делуня з того часу, як він по завершенню навчання був призначений диригентом Центрального філармонічного симфонічного оркестру, була пов'язана із активною розбудовою симфонічної складової музичної культури Китаю. Він з часом налагодив творчі комунікації 3 провідними солістами-виконавцями світового рівня і сам отримав міжнародне визнання. Важливим також було прагнення створити стале симфонічне середовище в Китаї, для чого Лі Делунь докладав значних зусиль.

Важливим чинником діалогу культур стали гастролі в Китаї західних музикантів, що розпочалися з 1978 р., з часу проголошення політики реформ та відкритості. Одним з перших серед таких музикантів став славнозвісний скрипаль Ісаак (Айзек) Стерн, який співпрацював із з оркестром під керуванням Лі Делуня. Його робота в КНР (а це концертні виступи, майстер-класи, читання лекцій китайським студентам тощо) мала величезне значення, вона стала ще одним поштовхом у русі китайських музикантів до осягнення не лише зовнішніх, технологічних проявів, а й також глибинних сенсів західної музичної культури. Свідченням значущості гастролей І. Стерна стало створення документального фільму сумісного американськокитайського виробництва «Від Мао до Моцарта: Ісаак Стерн у Китаї», знятого в 1979 р. режисером М. Лернером. У 1980 р. фільм був удостоєний премії «Оскар», а у 1981 також показаний на Канському кінофестивалі, що є, окрім визнання його високого художнього рівня, підтвердженням неординарності для того часу висвітлених у фільмі мистецьких процесів.

Політика реформ і відкритості впродовж кількох десятиліть позитивно проявляється в різних 
сферах суспільного життя Китаю. Як результат, «країна успішно просувалася до центру світової арени, вповні розкриваючи переваги $<\ldots>$ китайської культури» (Шэнь Хайсюн, 2021, с. 18). Проявом сучасного розквіту китайської симфонічної музики стала поява нових колективів і збагачення мистецьких практик чинних оркестрів.

У 1993 р. вперше в історії Китаю було проведено Національний конкурс оркестрових диригентів (журі очолював Лі Делунь). Проведення конкурсу, як і поява ще одного подібного заходу національного конкурсу диригентів імені Лі Делуня - мало велике значення і було зумовлене необхідністю висування нових талановитих диригентів, яких потребувала національна культура, зважаючи на відкриття концертних залів та заснування нових оркестрів.

Прикладом заснування нового мистецького простору стала побудова в 2011 р. у Харбіні Центру виконавських мистецтв (або Харбінського великого театру), що демонструє сміливість і вишуканість архітектурного рішення й раціональність внутрішнього облаштування. Після урочистого відкриття Центру в 2015 р. тут відбуваються різноманітні мистецькі заходи (оперні й балетні вистави, симфонічні концерти тощо), адже два зали, розраховані на 1538 і 414 місць, дають можливість реалізовувати найскладніші художні задуми.

Ще одним чинником здобуття китайським симфонізмом гідних позицій на світовій арені є успіхи національної композиторської школи. Творчі пошуки китайських композиторів останніх десятиліть (Бао Юань Кей, Го Веньцзін, Ян Цин, Ян Юн та ін.) втілюються в творах, що поєднують ознаки національної музики з усталеними європейськими жанровими моделями. Таким чином, через реалізацію засад стильового синтезу започатковано процеси стильової генерації.

Висновки. Становлення й розвиток симфонічної музики Китаю відбувалися впродовж тривалого часу в умовах плідної міжкультурної комунікації, що здійснювалася на особистісному та інституційному рівнях. Культурна дифузія, що розпочалася ще наприкінці XIX ст., була ознаменована появою на території країни перших симфонічних оркестрів, які сприяли запровадженню в китайський соціокультурний простір елементів чужорідної культури. Засвоєння останніх відбувалося через ознайомлення з новим явищем китайських слухачів, поступове залучення до виконавської практики китайських музикантів (1920-1930-ті pp.). Зазначимо, що вже на той час творчість композиторів у цій сфері була орієнтована також на національну традицію.

Період, що розпочався після Другої світової війни, став новою стадією становлення китайської симфонічної музики, позначеною активною творчою працею китайських музикантів, в тому числі тих, хто отримував музичну освіту в інших країнах і мав можливість засвоїти творчі й організаційні засади європейського симфонізму. Починаючи з діяльності Лі Делуня, в Китаї формується самобутня симфонічна школа, яка нині досягла стану зрілості. Якісне оновлення соціокультурного простору Китаю починаючи з 1980-х рр. сприяло набуттю нової якості в розвиткові симфонічного мистецтва, свідченням чого стали успіхи китайських оркестрів на міжнародній арені. Виконавська майстерність китайських музикантів та творчі досягнення китайських композиторів демонструють зрілість національного симфонічного стилю. Прояви цього стилю в композиторської творчості та діяльності виконавських колективів можуть стати основою подальших досліджень.

\section{Джерела та література}

Берегова О., Муха А., Шип С. (2008). Китайсько-українські музичні зв'язки. Українська музична енциклопедія. Київ : Інститут мистецтвознавства, фольклористики та етнології ім. М. Т. Рильського НАН України. С. 403-407.

Библер В. С., Ахутин А. В. (2000-2001). Диалог культур. Новая философская энииклопедия. Москва : Мысль. https://iphlib.ru/library/collection/newphilenc/document/ HASH01b0ec713aa8c5cb31f681b0

Ден Цзякунь (2019). Китайська оркестрова духова музика у контексті діалогу культур : дис. ...канд. мист. 17.00.03Музичне мистецтво. Львівська національна музична академія імені М. В. Лисенка. 193 с.

Дивеева Г. (2014). Харбинский симфонический оркестр: к проблеме влияния русской эмиграции на историю музыкальной культуры Китая. Общество. Среда. Развиmue (TERRA HUMANA). № 3. C. 68-71.

Зинькевич Е. С. (1986). Динамика обновления. Украинская симфония на современном этапе в свете диалектики традииий и новаторства (1970-е начало 80-х гг.). Киев : Музична Україна. 186 с.

Ли Цзинь (2012). Интегративные факторы развития современной китайской фортепианной школы (на материале украинско-китайских связей) : дисс. ...канд. искусствовед. 17.00.03 - Музыкальное искусство. Национальная академия наук Украины. Институт искусствоведения, фольклористики и этнологии им. М.Ф. Рыльского. 196 с.

Лі Мін (2019). Оперне мистецтво Китаю та Європи в контексті взаємовідображень : автореф. дис. ...канд. мист. (доктора філософії). 17.00.03 Музичне мистецтво. Харківський національний університет мистецтв імені І. П. Котляревського. $18 \mathrm{c.}$

Семенов Ю. И. (1997). Диффузия культурная. Культурология. $Х Х$ век : словарь. Санкт-Петербург : Университетская книга. С. 105-106.

Тышко С. (1994) Проблема национального стиля в русской опере. Глинка. Мусоргский. Римский-Корсаков. Киев : КГК им. П. И. Чайковского. 120 с. 
Ту Дуня (2010). Параллели художественного развития оперного театра Европы и Китая : дис. ...канд. искусствоведения. 17.00.03. Одес. гос. музык. Акад. им. А. В. Неждановой. $171 \mathrm{c}$.

Ху Пин (2013) Развитие украинских и китайских культурных традиций в камерно-инструментальных ансамблях второй половины XX века : дисс. ....канд. исскуствовед: 17.00.03. Львівська національна музична академія імені М. В. Лисенка. 218 с.

Чжу Чанлей (2006). Конвергенция восточной и западной художественной традиции в композиторской практике : дис... канд. искусствовед.: 17.00.03 / Национальная музыкальная академия Украины им. П.И. Чайковского. $203 \mathrm{c}$.

Шэнь Хайсюн (2021). Си Цзиньпин и политика реформ и открытости. Москва : Шанс. 799 с.

Янь Чао (2019). Трансформація модусу європейського драматичного театру в китайській розмовній драмі : дис. ...канд. мист. 17.00.02 - театральне мистецтво. Інститут мистецтвознавства, фольклористики та етнології ім. М. Т. Рильського НАН України. 289 с.

From Mao to Mozart: Isaac Stern in China (1979) (2009) The New York Times. Baseline \& All Movie Guide. June 10, 2009. URL: https://web.archive.org/web/20090611030533/http:// movies.nytimes.com/movie/226379/From-Mao-to-MozartIsaac-Stern-in-China/details (дата звернення 19.07.2021).

Smith C. (2012) China holds its first Li Delun National Conducting

Competition. URL: https://www.gramophone.co.uk/other/ article/china-holds-its-first-li-delun-national-conductingcompetition (дата звернення 14.08.2021).

Wang Hanlu (2010) UN recognizes China's northeastern Harbin as «Music City» http://en.people. $\mathrm{cn} / 90001 / 90776 / 90882 / 7041463 . \mathrm{html}$ (дата звернення 21.07.2021).

\section{References}

Berehova, O., Mukha, A., Ship, S. (2008). Kytaysko-ukrainski muzychni zviazky [Sino-Ukrainian musical ties]. Ukrainska muzychna encyklopedija. Kyiv : Instytut mystectvoznavstva, folklorystyki ta etnologii im. M. T. Rylskogo NAN Ukrainy. S. 403-407. [in Ukrainian]

Bibler, V., Akhutin, A. (2000-2001). Dialog kultur [Dialogue of cultures]. Novaja filosofskaja encyklopedia. Moskva : Mysl'. https://iphlib.ru/library/collection/newphilenc/document/ HASH01b0ec713aa8c5cb31f681b0 [in Russian]

Dan Jiakun (2019). Chinese orchestral wind music in the context of the dialogue of cultures : dissertation for the degree of the candidate of art studies on specialty 17.00.03 Musical art. The Mykola Lysenko Lviv National Music Academy. 193 s. [in Ukrainian]

Diveeva, G. (2014) Harbinskiy simfonicheskiy orkestr: k probleme vliyaniya russkoy emigratsii na istoriyu muzykalnoy kultury Kitaya [Harbin Symphony Orchestra: to the problem of the influence of Russian emigration on the history of Chinese musical culture]. Obshchestvo. Sreda. Razvitie. (TERRA HUMANA). № 3. S. 68-71. [in Russian]

Zin'kevich, E. (1986). Dinamika obnovlenija. Ukrainskaya simfoniya na sovremennom etape $v$ svete dialektiki tradicij $i$ novatorstva (1970-e nachalo 80-h gg.) [The dynamics of the update. Ukrainian symphony at the present stage in the light of the dialectic of tradition and innovation (1970s-early 80 s.)]. Kyiv: Muzychna Ukraina. 186 s. [in Russian]

Li Jin (2012). Integrative's link of contemporary Chinese's piano school's developing (Ukrainian-china's musical connections) : dissertation for the degree of the candidate of art studies on specialty 17.00.03 Musical art. National Academy of Sciences of Ukraine, Rylsky Institute of Art Studies, Folklore and Ethnology. Kyiv. 196 s. [in Russian]

Li Ming (2019). Opera art of China and Europe in the context of mutual representations : thesis for the degree of a Candidate of Art History (Doctor of Philosophy) in speciality 17.00.03 Musical Art. Kharkiv National University of Arts named after I. P. Kotlyarevsky, the Ministry of Culture of Ukraine, Kharkiv. 18 s. [in Ukrainian]

Semenov, Yu. (1997). Diffuziya kulturnaya [Diffusion cultural].

Kulturologiya.XX vek: slovar'. Sankt-Peterburg: Universitetskaya kniga. S. 105-106. [in Russian]

Tyshko, S. (1994). Problema nazionalnogo stilja v russkoi opera. Glinka. Musorgskij. Rimskij-Korsakov [The problem of national style in Russian opera. Glinka. Mussorgsky. RimskyKorsakov.]. Kiev : KGK im. P. I. Chajkovskogo. 120 s. [in Russian]

Tu Dunya (2010). Parallels in the artistic development of opera houses in Europe and China : dissertation for the degree of the candidate of art studies on specialty 17.00.03 Musical art. Odessa National A. V. Nezhdanova Music Academy. 171 s. [in Russian]

Hu Ping (2013). Development of Ukrainian and Chinese cultural traditions in chamber and instrumental ensembles of the second half of the twentieth century : dissertation for the degree of the candidate of art studies on specialty 17.00 .03 Musical art. The Mykola Lysenko Lviv National Music Academy. 218 s. [in Russian]

Zhu Changlei (2006). Convergence of Eastern and Western Artistic Traditions in Composing Practice: dissertation for the degree of the candidate of art studies on specialty 17.00.03 Musical art. Tchaikovsky National Music Academy of Ukraine 203 c. [in Russian]

Shen` Haisiun (2021). Si Tzin ’pin I politika reform i otkrytosti [Xi Jinping and the Reform and Openness Policy]. Moskva : Shans. 799 s. [in Russian]

Yan Chao (2019). Transformation of the mode of the European drama theater in the Chinese spoken drama : dissertation for achieving the degree of Ph.D. in History of Art. 17.00.02 «Performance Art». National Academy of Sciences of Ukraine. The Rylsky Institute of Art Studies, Folklore and Ethnology. 289 s. [in Ukrainian]

From Mao to Mozart: Isaac Stern in China (1979), (2009). The New York Times. Baseline \& All Movie Guide. June 10, 2009. URL: https://web.archive.org/web/20090611030533/http:// movies.nytimes.com/movie/226379/From-Mao-to-MozartIsaac-Stern-in-China/details [in English]

Smith C. (2012). China holds its first Li Delun National Conducting Competition. URL: https://www.gramophone. co.uk/other/article/china-holds-its-first-li-delun-nationalconducting-competition [in English]

Wang Hanlu (2010) UN recognizes China's northeastern Harbin as «Music City» http://en.people. cn/90001/90776/90882/7041463.html [in English] 


\section{Yang Jun}

\section{Formation and Development of China Symphonic Music in the Aspect of Cultural Dialogue Problem}

Abstract. The article is devoted to the processes of formation and development of symphonic music in China, which developed since the late nineteenth century as a result of adoption of models of western music culture. The action of the mechanisms of cultural diffusion, synthesis and assimilation, the way to stylistic adaptation and stylistic generation of symphonic music in China in different displays (institutional, educational, performing, composer's) is traced. The multipurposeness of the creative personalities of Chinese artists is demonstrated.

Key words: cultural dialogue, China symphonic music, composers' creative work, symphony orchestras, music education. 